\title{
A trophic indicators toolbox for implementing an ecosystem approach in data-poor fisheries: the Algerian and Bou-Ismail Bay examples
}

\author{
Karim Babouri ${ }^{1}$, M. Grazia Pennino ${ }^{2}$, José Maria Bellido ${ }^{3,4}$ \\ ${ }^{1}$ KMS Berkouka BP 19, Maatkas 15152, Tizi-Ouzou, Algeria. E-mail: babour2000dz@yahoo.fr \\ ${ }^{2}$ Institut de Recherche pour le Développement (IRD), UMR EME 212 (IRD/Ifremer/Université Montpellier 2), Centre de \\ Recherche Halieutique Méditerranéenne et Tropicale, Avenue Jean Monnet, B.P. 171, 34203 Sète cedex, France. \\ ${ }^{3}$ Instituto Español de Oceanografía, Centro Oceanográfico de Murcia, C/Varadero 1, San Pedro del Pinatar, \\ 30740 Murcia, Spain. \\ ${ }^{4}$ School of Biological Sciences, University of Aberdeen, Tillydrone Avenue, AB24 2TZ Aberdeen, Scotland, UK.
}

\begin{abstract}
Summary: Over the past decade, the Algerian government has undertaken several incentives financed by state subsidies, via a range of development plans for fishing activities. Although these have led to the growth and modernization of the fishing fleet and the creation of various jobs, this increased fishing pressure has not maximized production as anticipated. In fact, catch is decreasing, and there are clear signs of stock overexploitation for several species, particularly sardines, for which catches have fallen dramatically. This study analyses the impact of fishing from an ecosystem perspective, with a view to the implementation of ecosystem approach to fishery management (EAFM) at the level of Algerian fisheries. To this end, a series of trophic indicators are used. The analysis shows that ecosystems at both national level and in the Bou-Ismail Bay are excessively exploited, and are altered by overexploitation and probably eutrophication. This situation is demonstrated in particular by the decrease in the average trophic level of catch, which is synonymous with "Fishing Down Marine Food Webs" (FDMW).
\end{abstract}

Keywords: trophic indicators; ecosystem approach to fisheries management; Algerian fisheries; data-poor fisheries; BouIsmail Bay.

Herramientas basadas en indicadores tróficos para la implementación del enfoque ecosistémico en pesquerías con escasez de datos: ejemplos de Argelia y Bahía Bou-Ismail

Resumen: Durante la década pasada, el gobierno argelino puso en marcha varios incentivos de financiación estatal, a través de una serie de planes de desarrollo para actividades pesqueras. A pesar de que este hecho ha originado crecimiento y modernización en la flota pesquera, además de la creación de puestos de trabajo, este aumento de la presión pesquera no ha permitido aumentar la producción pesquera como se había previsto. De hecho, las capturas están decreciendo y hay claros signos de sobreexplotación en varias especies, particularmente la sardina, para la cual las capturas han descendido drásticamente. Este estudio analiza el impacto de la pesca desde una perspectiva ecosistémica, con vistas a implementar el enfoque ecosistémico en la ordenación pesquera argelina. Se utilizan una serie de indicadores tróficos para este fin. El análisis muestra que los ecosistemas están muy explotados, alterados por la sobreexplotación y probablemente eutrofizados, tanto a nivel nacional como en la bahía de Bou-Ismail. Esta situación ha quedado demostrada concretamente por el descenso en el nivel trófico medio de las capturas, que significa la pesca de los niveles inferiores de la cadena trófica marina.

Palabras clave: indicadores tróficos; enfoque ecosistémico para la gestión pesquera; pesquerías argelinas; pesquerías con escasez de datos; bahía Bou-Ismail.

Citation/Como citar este artículo: Babouri K., Pennino M.G., Bellido J.M. 2014. A trophic indicators toolbox for implementing an ecosystem approach in data-poor fisheries: the Algerian and Bou-Ismail Bay examples. In: Lleonart J., Maynou F. (eds), The Ecosystem Approach to Fisheries in the Mediterranean and Black Seas. Sci. Mar. 78S1: 37-51. doi: http://dx.doi. org/10.3989/scimar.04023.19B

Editors: Jordi Lleonart and Francesc Maynou.

Received: October 1, 2013. Accepted: January 10, 2014. Published: March 28, 2014.

Copyright: () 2014 CSIC. This is an open-access article distributed under the Creative Commons Attribution-Non Commercial Lisence (by-nc) Spain 3.0. 


\section{INTRODUCTION}

The FAO reported that in 2008, $85 \%$ of stocks were overexploited or fully exploited, and only $15 \%$ of stocks were underexploited or moderately exploited (FAO 2010). Furthermore, according to Worm et al. (2009), 63\% of the world's evaluated fish stocks still need rebuilding, and lower exploitation rates are required to prevent stocks of vulnerable species from collapsing.

This situation of generalized overexploitation is accompanied by economic wastage and habitat degradation (FAO 2003, Pauly et al. 2000), revealing the relative failure of traditional fisheries management methods based on conventional approaches that essentially focus on species of commercial interest and examine each stock separately (Garcia et al. 2003, Cury et al. 2005a).

At its $19^{\text {th }}$ session, held in March 1991, the FAO fisheries committee recommended those new approaches to fisheries management to be developed as a matter of urgency, taking into account conservation and environmental protection imperatives, as well as social and economic considerations (FAO 2003). This new management approach, known as the ecosystem approach to fisheries management (EAFM), is primarily based on the Code of Conduct for Responsible Fisheries (FAO 1995). The guidelines for its implementation were made official at the 2001 Reykjavík Conference on Responsible Fisheries in the Marine Ecosystem. All signatory countries (FAO 2001) accepted the final declaration of this conference, which stated that "In an effort to reinforce responsible and sustainable fisheries in the marine ecosystem, we will individually and collectively work on incorporating ecosystem considerations into that management."

However, the key problem lies in the practical application of the EAFM's politically and ethically correct instructions and suggestions (Garcia and Cochrane 2005). Moreover, it is difficult to define operational objectives, reference points and performance indicators for the ecosystem approach (Morishita 2008) in the absence of data on the original unexploited situations for use as recovery objectives (Gislason et al. 2000).

The major challenge in integrating ecosystem considerations into fisheries management is the definition of measurable indicators which take into account impacts on both the structure (biodiversity) and function (habitat productivity) of marine ecosystems (Gislason et al. 2000). To be useful, ecosystem indicators should be sensitive to differences in the integrity of ecosystems between places and over time. They should also be easily measurable, understandable, informative, based on accessible data, and able to integrate uncertainty (Link 2002).

Pauly et al. (1998) used the mean trophic level (MTL) of world catches between 1950 and 1994 from the FAO database to evaluate the sustainability of exploitation systems used throughout the world. The study showed that the trophic level of landings decreased gradually over time, and that fisheries progressively moved away from long-lived species from high trophic levels and benthic piscivores towards short-lived species, invertebrates and planktivorous pelagic fish (Pauly et al. 1998). This phenomenon, known as "Fishing Down Marine Food Webs" (FDMW), currently studied using the marine trophic index (MTI), which is the Commission for Biological Diversity's name (CBD 2004) for the MTL, has now been observed in several regions of the world: in Thailand (Christensen 1998), Canada (Pauly et al. 2001), Greece (Stergiou and Koulouris 2000), the common Argentine-Uruguayan fishing zone (Jaureguizar and Milessi 2008), Brasil (Freire and Pauly 2010), the Mediterranean and the Black Sea (Pennino et al. 2011), and elsewhere.

However, the use of the MTI alone to show FDMW has been criticized by Caddy et al. (1998). Criticisms include the fact that fishing towards the bottom of the trophic chain can be a conscious choice, and that the "bottom-up" phenomenon (an increase in primary production) in coastal zones and in semi-enclosed seas lowers the average trophic level of catch. These criticisms have led to the development of other indicators, which are currently used together to evaluate the state of ecosystems exploited by fishing. These include the "fishing-in-balance" (FiB) index developed by Pauly et al. (2000) to analyse (among other things) the expansion and contraction of fisheries, and the "cutmarine trophic index" (cutMTI) (Pauly and Watson 2005), which deals with abundance changes for species at intermediate and upper trophic levels, and with the evaluation of FDMW in the coastal systems of semi-enclosed seas. These indicators, along with the ratio of pelagic and demersal fish landings (P/D) (Caddy 2000), are easily obtained from generally available and accessible data on commercial fisheries landings. They are therefore perfectly suited for studying fisheries such us the Algerian ones for which few data are available.

In the present paper we develop a set of the aforementioned indicators with a combination of statistical techniques such as smoothing techniques and bootstrapping to assess the ecological balance of the Algerian marine ecosystem. First, we analyse fishery data collected in the Bou-Ismail Bay from 1999 to 2012 to obtain an accurate local spatial approach. Then we extend the analyses to all landings from 1999 to 2010 in order to study the fishery exploitation within an ecosystem perspective. Finally, we explore how environmental conditions, such as sea surface temperature (SST), chlorophyll- $a$ and rainfall concentrations can contribute to different levels of catch.

\section{MATERIALS AND METHODS}

\section{Study area}

The Bou-Ismail Bay (Algeria) is in the Algerian sub-basin of the western Mediterranean between $2^{\circ} 54^{\prime} \mathrm{E} 36^{\circ} 48^{\prime} \mathrm{N}$ and $2^{\circ} 24^{\prime} \mathrm{E} 36^{\circ} 38^{\prime} \mathrm{N}$. It is considered to be one of the most important bays on the Algerian coast regarding fisheries production. It has three fishing ports: Tipasa, Khemisti and Bouharoun. The ports of Khemisti and Bouharoun are the most important in the area in terms of fleet concentration and quantities 
landed. There is also a mooring beach (Fouka) and a converted fishing shelter (Bou-Ismail). As of December 2012, the fishing fleet in the ports of Bouharoun and Khemisti consists of 307 units, including 27 trawlers, 108 sardine boats and 172 small traders. The vessel concentration is higher at the port of Bouharoun (73\%). There are also a few yachtsmen at Khemisti and two tuna boats registered at Bouharoun.

\section{The data}

\section{Catch and fleet data}

The 1999-2012 catch and fleet data for the BouIsmail Bay were collected by the Fisheries and Marine Resources Directorate (Direction de la Pêche et des Ressources Halieutiques, or DPRH) of the wilaya (province) of Tipasa, which is the authority in charge of fishing in this zone. Catch data concern all the landings by the fleet's four segments (trawlers, sardine boats, small traders and yachtsmen) for the bay's two main ports (Bouharoun and Khemisti).

The total annual catch data for 1999 to 2010 are from the General Fisheries Commission for the Mediterranean (GFCM) database, on the website http:// www.fao.org/fishery/statistics/GFCM-capture-production/query/en. The data on the Algerian national fleet are from the website of the Ministère de la Pêche et des Ressources Halieutiques (MPRH) (http://www. mpeche.gov.dz).

\section{The environmental data}

For ocean processes, chlorophyll- $a$ (Chl- $a$ ) concentration and SST data can be used to locate thermal and productivity-enhancing fronts and marine productivity hotspots and thus determine the influence of such features on species distribution. In addition, SST and Chl- $a$ are also strong functional links between surface primary productivity and biological activity at the sea floor through the episodic deposition of particulate material (Aminot and Chaussepied 1983).

The environmental satellite (SST and Chl- $a$ ) data were extracted as a monthly mean from the Environmental Marine Information System (EMIS) online platform (http://emis.jrc.ec.europa.eu/), using two sensors, SeaWiFS (January 1999-Decembrer 2003) and MODIS-A (January 2004-December 2012), at a resolution of $4 \mathrm{~km}$.

In addition, in order to assess nutrient input in the ecosystem, we analysed rainfall data $(\mathrm{mm} / \mathrm{h})$. The monthly means were obtained using the "Time series" function at the web platform GIOVANNI (http://disc. sci.gsfc.nasa.gov/giovanni) at a resolution of $1 \mathrm{~km}$.

\section{The trophic levels of landed species}

Trophic indicators are highly sensitive to the trophic level (TL) attributed to landed species. The difficulty of attributing TLs to landed species lies in the fact that most catches are assigned to species groups that above all concern landings statistics for the Bou-
Ismail Bay. Pauly et al. (1998) emphasized this problem by analysing the global catch data from the FAO database in terms of TLs. Consequently, the database was first disaggregated into taxonomic species based on FishBase and certain documents dealing with fauna surveys on the Algerian coasts, primarily Massuti et al. (2004), PNUE (2005), Hemida (2005) and Refés et al. (2010). The TL and the standard error for each species were then assigned according to FishBase (www. fishbase.org), or in some cases according to Stergiou and Karpouzi (2002) for fish, and SeaLifeBase (www. sealifebase.org) for molluscs and crustaceans. These TLs were estimated, mostly based on the species' diets (Table 1 and 2).

The TLs for giant red shrimp (Aristaeomorpha foliacea) and common shrimp (Melicertus kerathurus) were unavailable. To these two species, we have attributed the TLs of the blue and red shrimp (Aristeus antennatus) and the deep-water rose shrimp (Parapenaeus longirostris), respectively. It should be noted that the "other osteichthyes" group in the GFCM database was not included in the calculation of trophic indicators because it was impossible to attribute a TL to this group.

\section{The ecosystem indicators used}

\section{Pelagic/demersal ratio}

The pelagic/demersal (P/D) ratio is defined as the ratio of pelagic species landings to demersal species landings (in weight). Eutrophication and/or overexploitation are the key phenomena that can influence the trend for this ratio (Caddy 1993, 2000, De Leiva Moreno et al. 2000, Libralato et al. 2004, Pennino and Bellido 2012). In fact, pelagic species (mainly small pelagic planktivores) are positively affected by the increase in nutrients which stimulate primary production (Caddy 1993), whereas demersal species are negatively affected by the hypoxia arising from the excess of primary production. Consequently, the P/D ratio indirectly indicates nutrient availability levels (De Leiva Moreno et al. 2000).

The P/D ratio is also useful for studying the overall evolution of the fishery. In fact, a high demand for demersal fish and an increase in the P/D ratio can be explained by an overexploitation of demersal species (Pennino and Bellido 2012). Moreover, like other catch-based indicators, it is sensitive to the evolution of target species and fishing methods (Pennino et al. 2011). As a result, this ratio is compared with landings for certain species groups that are important to the fishery and to the evolution of the fishing fleet.

The influence of eutrophication on the fishery and the ecosystem is analysed by comparing the P/D ratio with certain environmental parameters, namely Chl- $a$ and SST, which are indicators of primary production, and precipitation, which causes soil runoff.

In this study, species are classified as pelagic or demersal according to FishBase (see Table 3). When calculating the $\mathrm{P} / \mathrm{D}$ ratio, we only consider small, mainly planktivorous fish like Clupeidae (sardines 
Table 1. - The trophic levels (TL) with their corresponding standard errors (se) and average annual catches (C) in tonnes for species or groups of species landed between 1999 and 2012 in the Bou-Ismail Bay.

\begin{tabular}{|c|c|c|c|c|c|c|c|}
\hline Species & $\mathrm{TL}$ & se & $\mathrm{C}$ & Species & $\mathrm{TL}$ & se & $\mathrm{C}$ \\
\hline Demersal fish & & & & Small pelagics & & & \\
\hline Mullus spp. & 3.30 & 0.45 & 138.01 & Sardinella spp. & 3.13 & 0.33 & 891.10 \\
\hline Boops boops & 3.30 & 0.47 & 228.02 & Engraulis encrasicolus & 3.10 & 0.45 & 39.06 \\
\hline Pagellus erythrinus & 3.53 & 0.52 & 157.20 & Sardina pilchardus & 3.10 & 0.20 & 3781.57 \\
\hline Spicara spp. & 3.60 & 0.35 & 0.11 & Trachurus spp. & 3.50 & 0.47 & 628.97 \\
\hline Sparus aurata & 3.30 & 0.50 & 1.73 & Scomberi spp. & 3.40 & 0.50 & 33.60 \\
\hline Dentex dentex & 4.30 & 0.65 & 0.01 & Clupeoidei & 3.33 & 0.43 & 18.47 \\
\hline Pagrus spp. & 3.55 & 0.55 & 8.39 & Large pelagics & & & \\
\hline Diplodus sargo & 3.05 & 0.34 & 0.69 & Auxis thazard and $A$. rochei & 4.10 & 0.60 & 0.01 \\
\hline Oblada melanura & 3.00 & 0.10 & 0.27 & Seriola dumerili & 4.50 & 0.80 & 5.98 \\
\hline Micromesistius poutassou & 4.00 & 0.70 & 23.97 & Sphyraena spp. & 4.00 & 0.51 & 8.97 \\
\hline Merluccius merluccius & 4.40 & 0.80 & 0.38 & Sarda sarda & 4.15 & 0.65 & 9.97 \\
\hline Epinephelus spp. & 3.90 & 0.60 & 1.21 & Xiphias gladius & 4.50 & 0.60 & 66.60 \\
\hline Soleidae & 3.26 & 0.41 & 11.04 & Thunnus thynnus & 4.35 & 0.75 & 5.60 \\
\hline Pleuronectidae & 4.00 & 0.65 & 0.03 & Euthynnus alletteratus and & & & \\
\hline Scophthalmidae & 3.97 & 0.72 & 0.08 & Orcynopsis unicolor & 4.50 & 0.80 & 0.90 \\
\hline Scorpaenidae & 3.88 & 0.62 & 0.33 & Pelagic sharks & 4.18 & 0.62 & 13.04 \\
\hline Phycis spp. & 4.00 & 0.65 & 0.01 & Various bony fish & 4.21 & 0.63 & 0.27 \\
\hline Triglidae & 3.55 & 0.52 & 0.18 & Crustaceans & & & \\
\hline Sarpa salpa & 2.00 & 0.00 & 2.14 & Aristeus antennatus & 3.30 & 0.47 & 55.19 \\
\hline Liza aurata & 2.50 & 0.20 & 0.07 & Aristaeomorpha foliacea & 3.30 & 0.47 & 3.64 \\
\hline Dicentrarchus labrax & 3.80 & 0.60 & 1.27 & Parapenaeus longirostris & 3.30 & 0.44 & 95.18 \\
\hline Argyrosomus regius & 4.30 & 0.75 & 0.01 & Crangon crangon & 3.30 & 0.44 & 2.03 \\
\hline Conger conger & 3.93 & 0.70 & 0.06 & Palinurus spp. & 3.34 & 0.66 & 0.20 \\
\hline Muraena helena & 3.80 & 0.60 & 0.14 & Nephrops norvegicus & 2.83 & 0.31 & 0.01 \\
\hline Torpedo spp. & 4.50 & 0.80 & 0.96 & Crustacea & 3.19 & 0.47 & 2.12 \\
\hline Rajiformes & 3.79 & 0.56 & 9.66 & Molluscs & & & \\
\hline Myliobatiformes & 4.16 & 0.55 & 0.01 & Octopodidae & 3.65 & 0.64 & 26.75 \\
\hline Scyliorhinus spp. & 3.70 & 0.60 & 0.06 & Loligo spp. & 4.06 & 0.77 & 8.66 \\
\hline Squalus acanthias & 4.00 & 0.50 & 0.09 & Sepia officinalis & 3.56 & 0.56 & 19.38 \\
\hline Elasmobranchii & 3.68 & 0.54 & 77.51 & Various molluscs & 3.77 & 0.67 & 10.33 \\
\hline
\end{tabular}

Table 2. - The trophic levels (TL) with their relative standard errors (se) and average annual catches (C) in tonnes for species or groups of species landed between 1999 and 2010, at national level.

\begin{tabular}{|c|c|c|c|c|c|c|c|}
\hline Species & TL & se & $\mathrm{C}$ & Species & TL & se & $\mathrm{C}$ \\
\hline Solea solea & 3.10 & 0.30 & 274 & Clupeoidei & 3.11 & 0.33 & 1727.6 \\
\hline Merluccius merluccius & 4.40 & 0.80 & 488 & Engraulis encrasicolus & 3.10 & 0.45 & 2806 \\
\hline Phycis blennoides & 3.70 & 0.60 & 29.2 & Sardina pilchardus & 3.10 & 0.20 & 60306 \\
\hline Boops boops & 3.30 & 0.47 & 5605 & Sardinella spp. & 3.13 & 0.33 & 21032 \\
\hline Pagellus erythrinus & 3.40 & 0.50 & 1227 & Trachurus spp. & 3.50 & 0.47 & 13466 \\
\hline Dicentrarchus labrax & 3.80 & 0.60 & 19 & Scomber scombrus & 3.70 & 0.60 & 1322.2 \\
\hline Trachinus draco & 4.20 & 0.71 & 2 & Sphyraena spp. & 4.15 & 0.66 & 360.75 \\
\hline Epinephelus spp. & 3.83 & 0.58 & 69.8 & Seriola dumerili & 4.50 & 0.80 & 306.33 \\
\hline Serranidae & 3.82 & 0.59 & 0.5 & Thunnus thynnus & 4.40 & 0.80 & 1245 \\
\hline Mugilidae & 2.50 & 0.20 & 110 & Sarda sarda & 4.50 & 0.70 & 706 \\
\hline Pagrus spp. & 3.70 & 0.60 & 322 & Auxis thazard and A. rochei & 4.20 & 0.65 & 550.5 \\
\hline Sparidae & 3.10 & 0.35 & 0.58 & Euthynnus alletteratus & 4.50 & 0.80 & 213.83 \\
\hline Pagrus pagrus & 3.70 & 0.60 & 141 & Orcynopsis unicolor & 4.50 & 0.80 & 54.833 \\
\hline Oblada melanura & 3.00 & 0.10 & 6.83 & Katsuwonus pelamis & 3.80 & 0.60 & 17.417 \\
\hline Sarpa salpa & 2.00 & 0.00 & 36 & Xiphias gladius & 4.50 & 0.60 & 706.83 \\
\hline Lithognathus mormyrus & 3.40 & 0.50 & 4.08 & Aristeus antennatus & 3.30 & 0.47 & 1020.4 \\
\hline Mullus spp. & 3.30 & 0.45 & 1659 & Palaemon serratus & 2.69 & 0.32 & 0.75 \\
\hline Diplodus sargus & 3.00 & 0.30 & 15.1 & Crangon crangon & 3.23 & 0.40 & 3.3333 \\
\hline Conger conger & 4.30 & 0.80 & 6.25 & Parapenaeus longirostris & 3.30 & 0.44 & 1317.3 \\
\hline Zeus faber & 4.50 & 0.80 & 0.42 & Crustacea & 3.12 & 0.43 & 93.75 \\
\hline Lophius spp. & 4.50 & 0.80 & 35.3 & Nephrops norvegicus & 2.83 & 0.31 & 66.5 \\
\hline Scorpaenidae & 3.72 & 0.57 & 77.8 & Palinurus spp. & 3.34 & 0.66 & 63.833 \\
\hline Scyliorhinus spp. & 3.85 & 0.55 & 41.5 & Cephalopoda & 3.77 & 0.68 & 93.75 \\
\hline Squalidae & 4.15 & 0.65 & 26.3 & Sepia officinalis & 3.56 & 0.56 & 356.67 \\
\hline Squalus acanthias & 4.30 & 0.70 & 4 & Loligo spp. & 4.10 & 0.85 & 209.58 \\
\hline Rajiformes & 3.79 & 0.56 & 339 & Mollusca & 3.77 & 0.68 & 13.5 \\
\hline Elasmobranchii & 4.10 & 0.61 & 217 & Octopodidae & 3.65 & 0.64 & 646.5 \\
\hline
\end{tabular}

and sardinellas) and Engraulidae (anchovies) as pelagic. Mid-sized pelagics (jack and horse mackerels, Trachurus spp., and mackerels, Scomber spp.) are not included in the analysis, because their diet includes small pelagic fish and squid as well as plankton (De Leiva Moreno et al. 2000). The same applies to golden grey mullet (Lisa aurata), which is a catadromous species, and to unidentified fish (Marine fishes nei) on the
MPRH database, given that they cannot be considered pelagic or demersal.

\section{Marine trophic index}

The MTI is one of the eight indicators identified at the February 2004 Convention on Biological Diversity $\mathrm{CBD}$ ) by the Conference of the Parties for use 
in evaluating progress in the slowing of biodiversity reduction (CBD 2004). It was developed as part of the UBC Fisheries Centre's (www.fisheries.ubc.ca) project (www.seaaroundus.org), and was introduced in order to examine the impact of fisheries on the world's marine ecosystems. The MTI is calculated for each year $k$ using the following formula:

$$
M T I_{k}=\sum_{i}\left(T L_{i}\right)\left(Y_{i}\right) / \sum_{i} Y_{i}
$$

where MTI is the mean trophic level of landings for the year $k, Y_{i}$ represents landings of the trophic group $i$, and $\mathrm{TL}$ is the trophic level of the species or trophic group $i$.

\section{The ${ }^{\text {cut }}$ marine trophic index}

The eutrophication phenomenon in coastal zones and semi-enclosed seas (caused by runoff waters and anthropogenic inputs) increases primary production and therefore the abundance of planktivorous species, which lower the mean TL of catch, creating confusion with FDMW (Caddy et al. 1998). One particularly illustrative example is the Peruvian anchoveta (Engraulis ringens). Massive catches of this species heavily influence the TL of overall catches (Pauly et al. 1998).

To avoid this problem, Pauly and Watson (2004) have suggested that all low-TL species should be excluded from the calculation, producing a new indicator

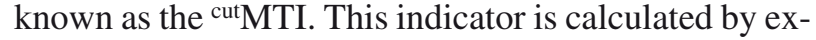
cluding all species belonging to TLs below 3.25, such as herbivores, detritivores and planktivores, which exhibit significant fluctuations in response to environmental conditions.

\section{Fishing-in-balance index}

Pauly et al. (2000) revealed a problem with using the decrease in the mean TL of landings as proof of a given fishery's impact on the ecosystem. Thus, in order to correctly evaluate the impact of fishing, the assessment should not be based uniquely on an index that decreases when the fishery is oriented towards the bottom of the trophic chain for a given ecosystem (Pauly et al. 2000).

Moreover, marine ecosystems function like pyramids in which the primary production generated at $(\mathrm{TL}=1)$ is displaced upwards to the TL above with a considerable rate of loss, when used in the maintenance processes, reproduction and other activities of the animals within the systems (Pauly and Christensen 1995). Inversely, biological production increases by a factor of ten with a downward move of just one level (Pauly et al. 2000). Consequently, displacement towards the bottom of the food chain can be the result of a conscious choice, given that biological production is higher at lower TLs (Pauly et al. 2000, Pauly and Watson 2005).

To avoid these production losses, a decrease in the average TL of catches should be compensated by an appropriate ecological increase of these catches (in biomass terms). This increase is determined by the transfer efficiency (TE) between TLs (Pauly and Watson 2005). Thus, Pauly et al. (2000) proposed the FiB index, including the notion of TE and making it pos- sible to evaluate whether or not a fishery is balanced in ecological terms. The FiB index for the year $i$ of a historical series is defined by the equation

$$
F i B=\log \left[Y_{i}\left(\frac{1}{T E}\right)^{T L_{i}}\right]-\log \left[Y_{0}\left(\frac{1}{T E}\right)^{T L_{0}}\right]
$$

where Y represents catch, TE is the transfer coefficient (0.1, according to Pauly and Christensen 1995), and 0 is the base year (1999 for the purposes of this study).

Pauly and Watson (2005) define the evolution of FiB as follows:

it remains constant $(\mathrm{FiB}=0)$ if the changes in $\mathrm{TL}$ are compensated by "ecologically correct" changes in catches;

it increases $(\mathrm{FiB}>0)$ if there is a "bottom-up" effect (a geographical expansion of fishing, and exploitation of a wider ecosystem);

it decreases $(\mathrm{FiB}<0)$ if discards are not taken into account in catches, or if the fishery removes so much biomass from the ecosystem that its operation is altered.

\section{Statistical analysis}

The statistical analysis was conducted using the $\mathrm{R}$ software (R Development Core Team 2013). To evalu-

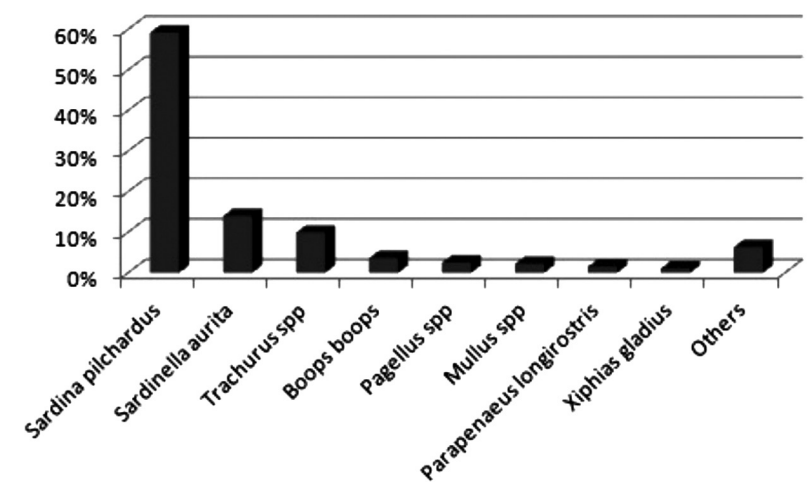

Fig. 1. - Species composition of landings in the Bou-Ismail Bay (only species for which the average catch is equal to or above $1 \%$ are shown: the other species or species groups for which catches below $1 \%$ are collectively accounted for as "Others").

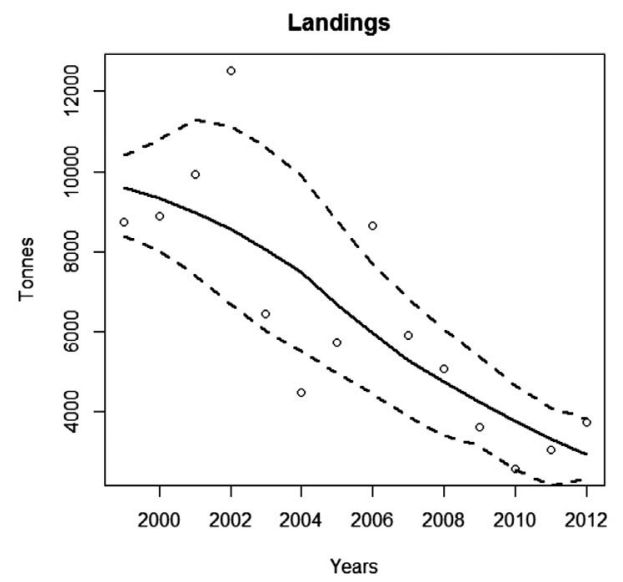

Fig. 2. - Landings in the Bou-Ismail Bay from 1999 to 2012. The continuous line represents the fit of the landings and the dotted lines show the $95 \%$ confidence bands. Locally-weighted regression and bootstrapping was used to obtain the smoothing curve and confidence intervals. 
A
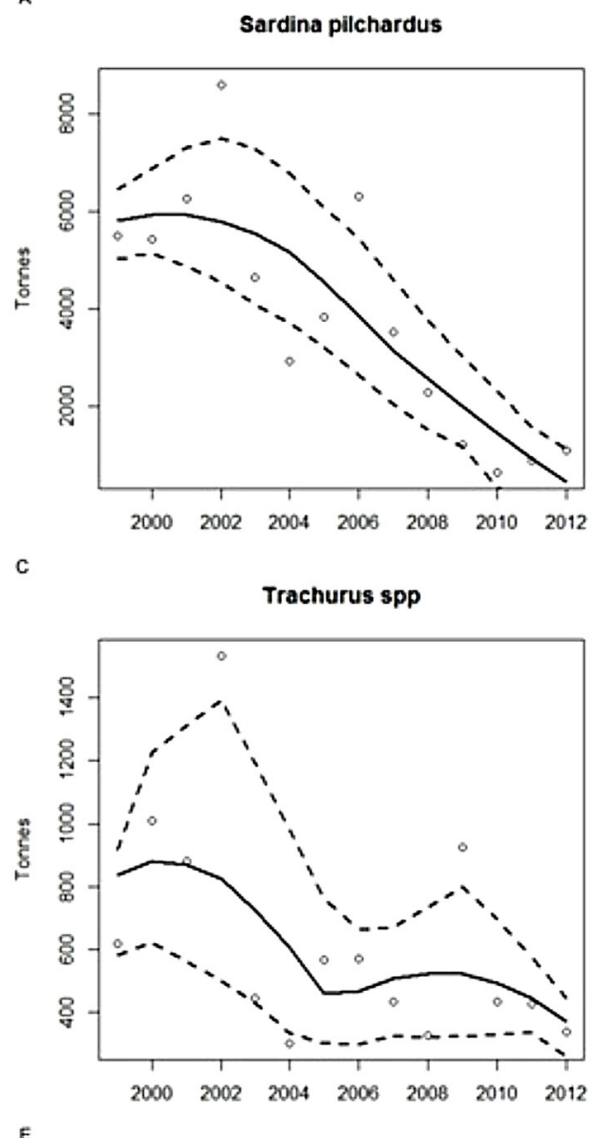

E

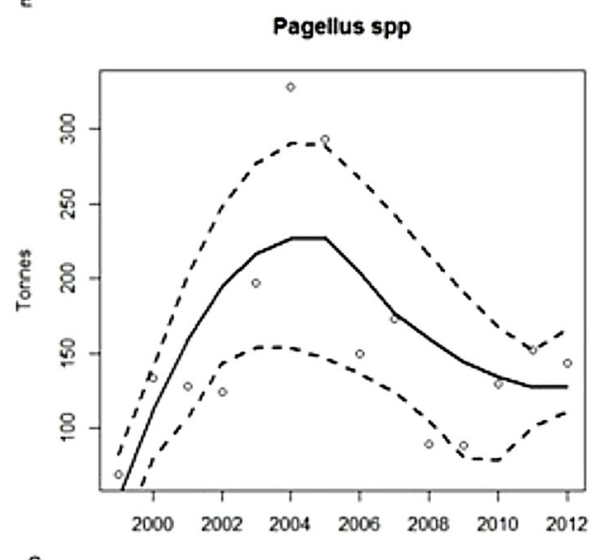

G



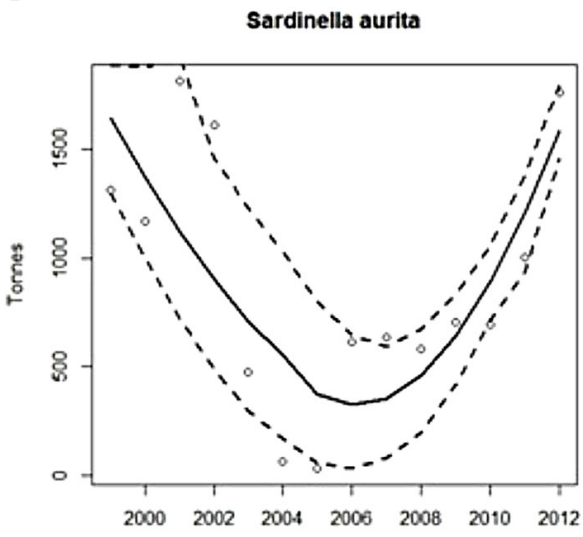
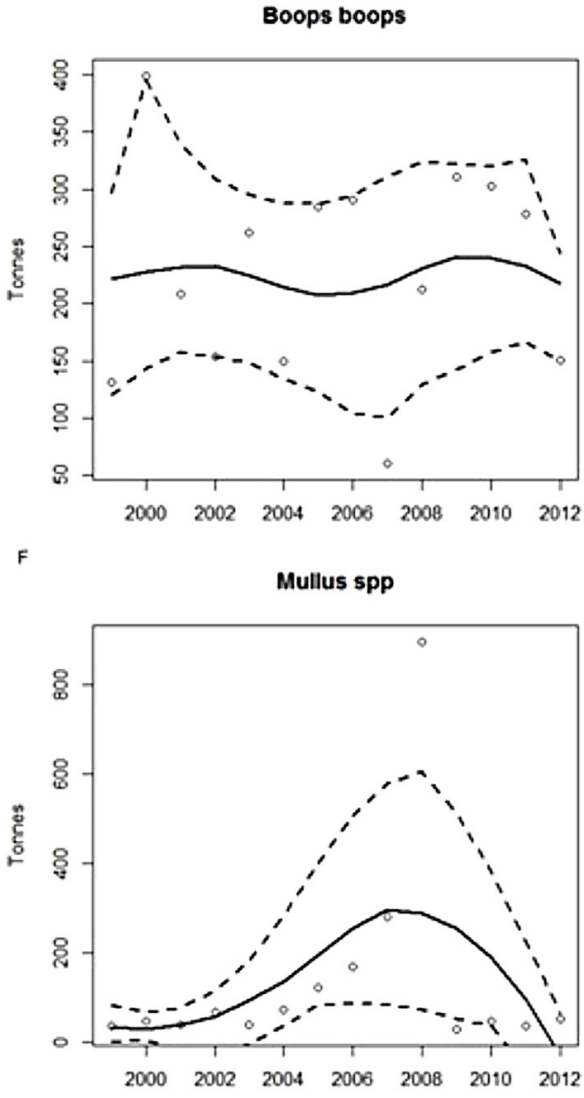

H

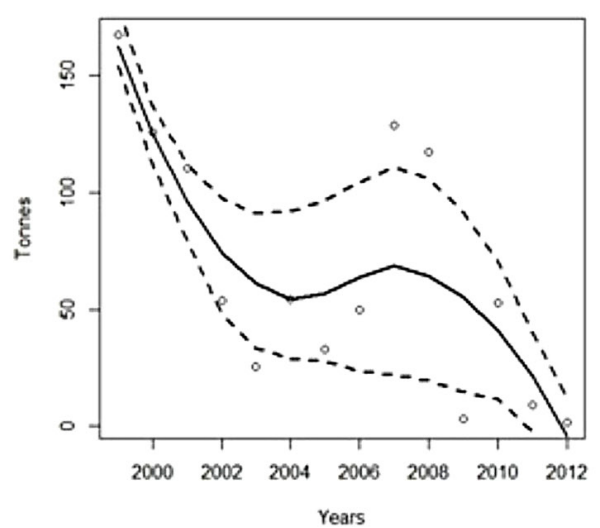

Fig. 3. - Landings of the main species caught in the Bou-Ismail Bay from 1999 to 2012. 
A
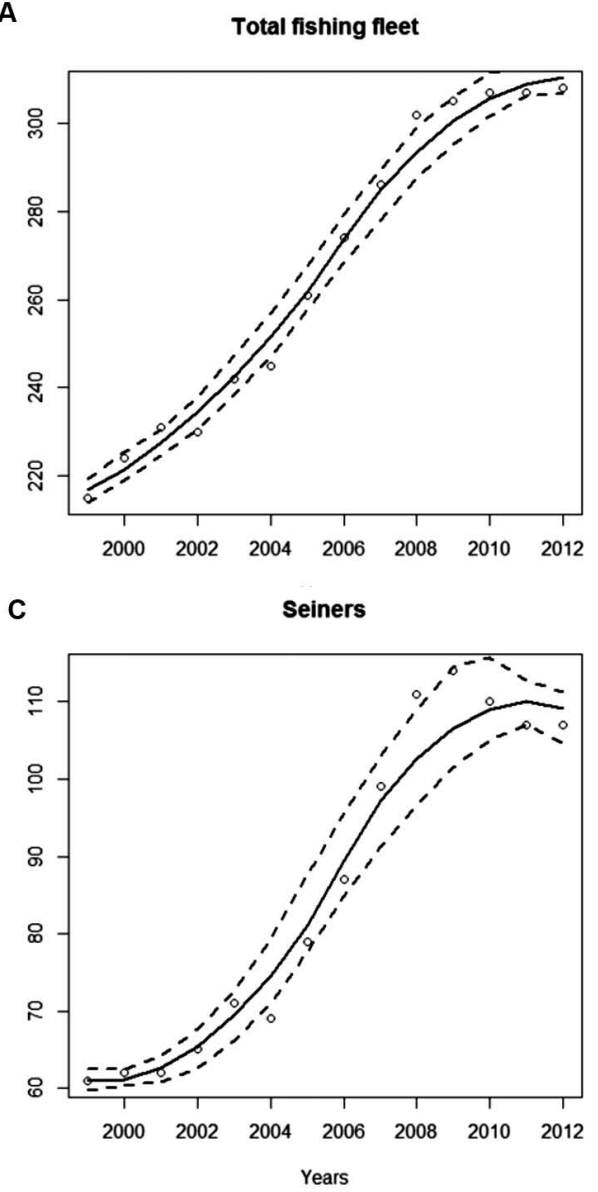

B
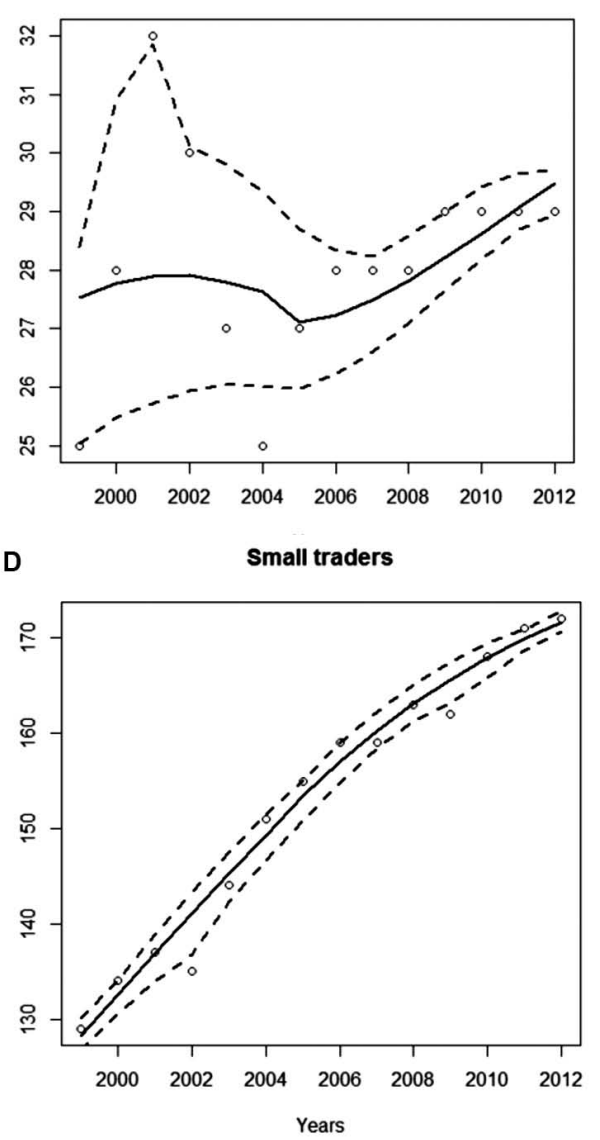

Fig. 4. - Total fishing fleet (A), trawlers (B), sardine boats (C) and small traders (D) working in the Bou-Ismail Bay between 1999 and 2012.

ate the statistical variability of the parameters studied, we used the bootstrap method (Efron 1979). For curve fitting, we applied the "Loess" locally-weighted regression method (Cleveland 1979), with a smoothing factor ( $\operatorname{span}=1)$. A confidence interval of $95 \% \mathrm{ob}-$ tained from 1000 bootstrap replicas was calculated for the Loess smoothing (see Pennino et al. 2011 for more information).

\section{RESULTS}

\section{The Bou-Ismail Bay}

The species composition of landings (Fig. 1) shows the dominance of sardines (Sardina pilchar$d u s$ ), constituting over $59 \%$ of landings, followed by round sardinella (Sardinella aurita), at around 14\% of catch. These two small pelagic species make up $73 \%$ of the Bou-Ismail Bay fishery's average annual fishing production.

The total annual landings (Fig. 2) declined constantly during the years studied, falling from over 8000 $\mathrm{t}$ to less than $4000 \mathrm{t}$ : a decrease of over $50 \%$. This significant fall in fishing production is due to the decline in sardine catch (Fig. 3), which fell from over $5000 \mathrm{t}$ to around 1000 t between 1999 and 2012. Other species showing declining production included jack and horse mackerels (Trachurus spp.), (Fig. 3), deep-water rose shrimp (Parapenaeus longirostris) and swordfish (Xiphias gladius). In contrast, round sardinella (Sardinella aurita) and the principal demersal fish, namely bogue (Boops boops), pagellus (Pagellus spp.) and red mullets (Mullus spp.), alternated between periods of rising and falling catch (Fig. 3).

The total fishing fleet (Fig. 4A) increased significantly during the years considered, from 215 units in 1999 to 308 units in 2012: an increase of 93 units with a $43 \%$ rate. The significant increases were for sardine boats (Fig. 4C) and small traders (Fig. 4D), 46 and 43 additional units respectively, with respective rates of $75 \%$ and $33 \%$. Trawler numbers (Fig. 4B) barely changed: from 24 units in 1999 to 29 units in 2012.

The fishing fleet includes boats from Tipasa province, with Bouharoun and Khemisti as landing ports. However, although an official census of fishing boats exists, it is very difficult to define the fishing effort exerted on marine resources in the Bou-Ismail Bay. Indeed, the number of the fleet registered is not truly representative of the real fleet operating in the bay. Several registered vessels are not operational (wrecks, missing boats, etc.) and there is also a significant movement of vessels between fishing grounds of the Algerian coast that is difficult to monitor. Due to this lack of finer data, our main interest is to study the trend of the fishing fleet and how it evolves throughout the study period, and how this can affect the ecosystem. 

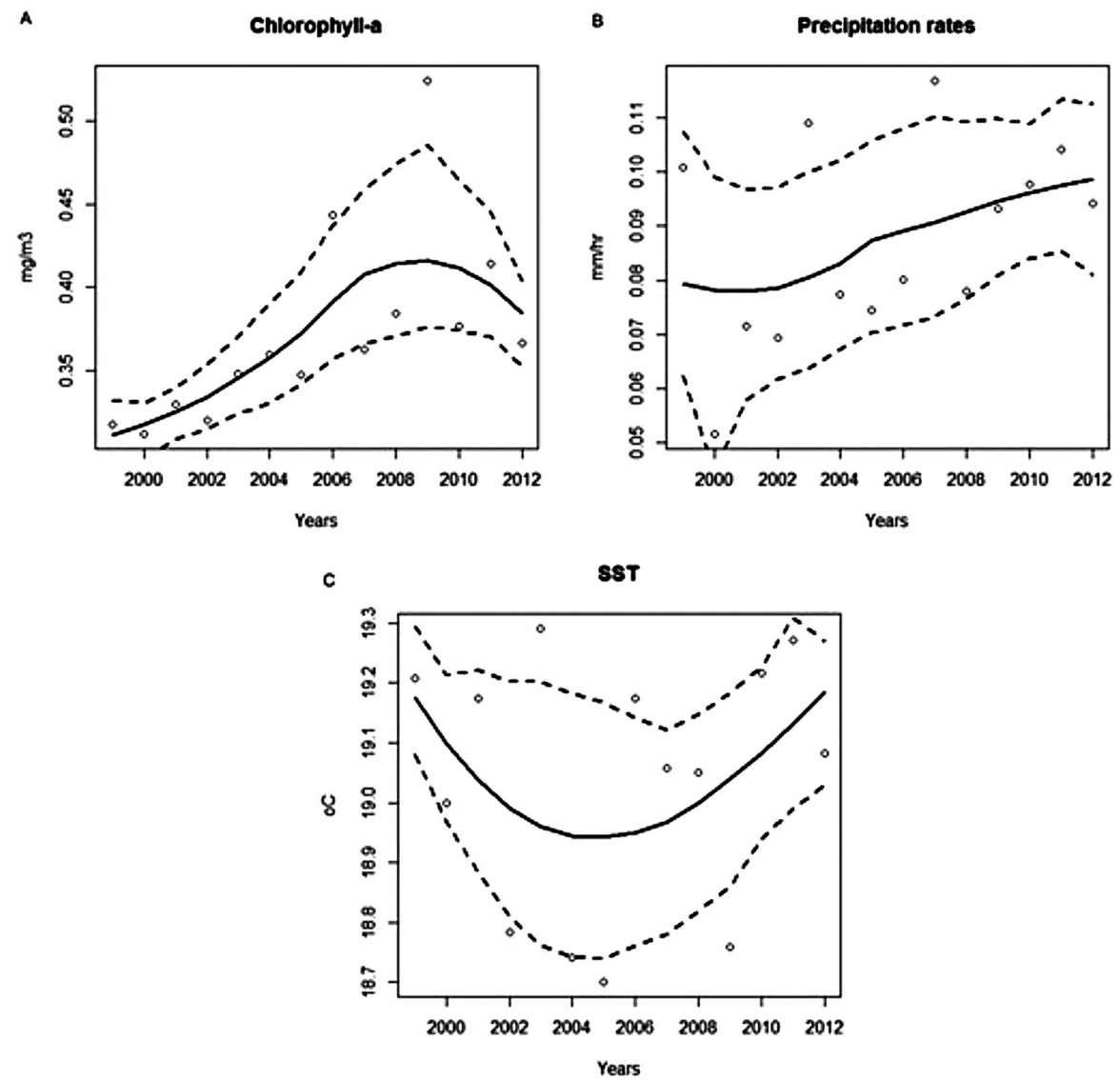

Fig. 5. - Chlorophyll- $a$ concentration (A), precipitation rates (B) and sea surface temperature (C) in the Bou-Ismail Bay from 1999 to 2012.
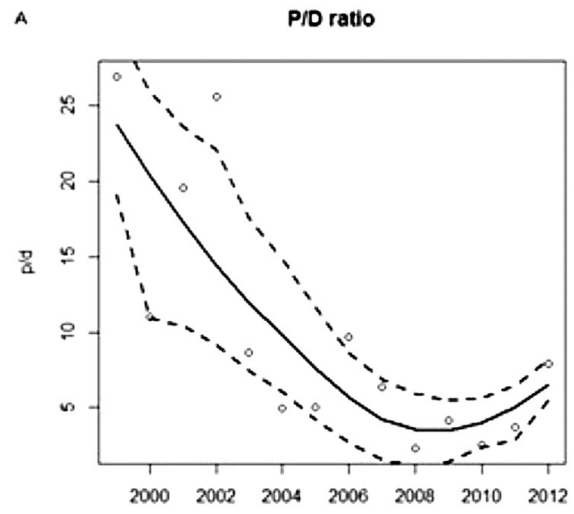

$\mathrm{c}$



B

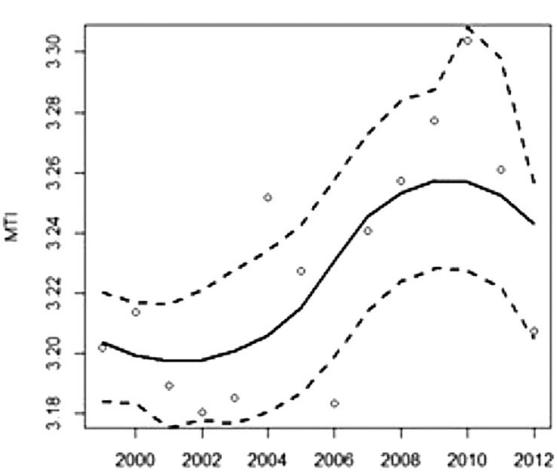

D

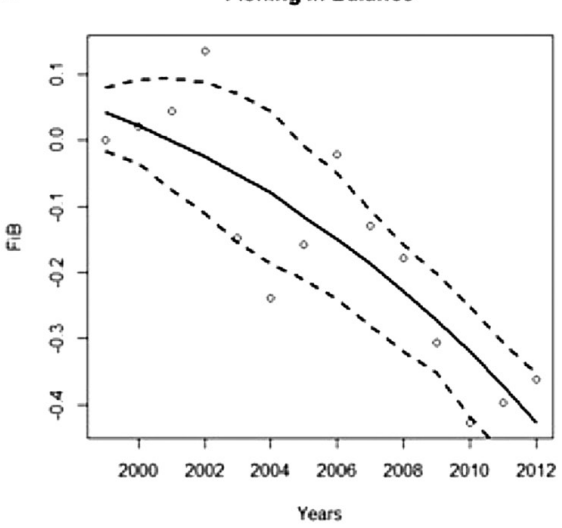

Fig. 6. - Trophic indicators for catches in the Bou-Ismail Bay from 1999 to 2012. 
Regarding the environmental variables, Chl- $a$ (Fig. $5 \mathrm{~A}$ ) increased until 2008 , peaking at $0.41 \mathrm{cmg} / \mathrm{m}^{3}$. It then decreased slightly while precipitation levels rose constantly during the period considered, from $692 \mathrm{~mm}$ $(0.08 \mathrm{~mm} / \mathrm{h})$ in 1999 to around $858 \mathrm{~mm}(0.1 \mathrm{~mm} / \mathrm{h})$ in 2012 (Fig. 5B). The SST exhibited a gradual increase from 2007 in Algerian waters, reaching the maximum value of $19.27^{\circ} \mathrm{C}$ in 2012 (Fig. 5C).

Among the trophic indicators, after reaching 24 in 1999, the P/D index (Fig. 6A) decreased slightly until 2008 , to a low of 3.5. A slight increase then began. The annual average calculated for the period in question is estimated at 9.9.

The average MTI for the series in question is estimated at around 3.23. During the first six years, the values for the MTI (Fig. 6B) were at their lowest for the period in question $(\sim 3.2)$. This coincided with high catches of sardines (Sardina pilchardus) from a low TL of 3.1. Subsequently, the MTI rose, whereas sardine catch continued to fall. MTI values were at their highest during the last years, reaching a peak of 3.26 in 2009 and coinciding with the lowest sardine catches. However, at the very end of the series, the MTI began to fall. This trend explains the high catches of round sardinella (Sardinella aurita) with a low $\mathrm{TL}(\mathrm{TL}=3.13)$. In fact, this species became the dominant species in landings from 2009 , constituting almost $47 \%$ of overall catch in 2012 , and exceeding sardine catch (Fig. 7).

If species of $\mathrm{TL}<3.25$ (salema, golden grey mullet, Norway lobster, saddled seabream, sargo bream, anchovy, sardine, round sardinella and various crustaceans) are excluded from the calculation, the average TL of catch $\left({ }^{3.25} \mathrm{MTI}\right)$ from 1999 to 2012 is estimated at 3.52. It is very close to that of jack and horse mackerels (Trachurus spp.) and pagellus (Pagellus spp.). The ${ }^{3.25}$ MTI (Fig. 6C) fell throughout the period studied. It decreased from 3.56 in 1999 to 3.49 in the final year of the series. This decrease of TLs by 0.07 over the 14 years studied is mainly due to the jack and horse mackerel catch declining by over 50\%. In fact, if sardine and round sardinella catches are removed from the calculation, jack and horse mackerel, of medium TL ( TL =3.5), become dominant, consequently impacting considerably on the ${ }^{3.25}$ MTI trend. The increase in Pagellus spp., $(\mathrm{TL}=0.53)$ catch during the early years did not alleviate the effects of falling catches of jack and horse mackerel and swordfish (Xiphias gladius), of TL 4.5. From 2005, catches fell for all of the fishery's major low- and medium-TL species, accentuating the fall in ${ }^{3.25} \mathrm{MTI}$ to its lowest values in the series.

The FiB shows a clear declining trend during the period in question, with negative values from 2002 onwards (Fig. 6D). In fact, a value of 0.05 was recorded in 1999, and a value of -0.45 was recorded in 2012 . This decrease was accompanied by a decrease in overall catch.

\section{At national level}

The average national fishing production is estimated at 126300.5 tonnes. Like the Bou-Ismail fishery, it is dominated by small pelagics, mostly sardine (Sar-

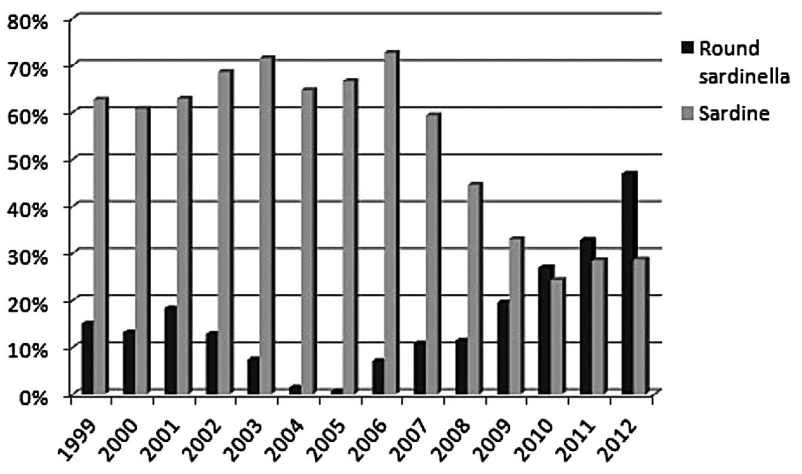

Fig. 7. - Sardine and round sardinella catch levels in the Bou-Ismail Bay from 1999 to 2012.

dina pilchardus) at $46 \%$ of total landings, followed by round sardinella (Sardinella aurita) at $17 \%$, and jack and horse mackerels (Trachurus spp.) at 11\% (Fig. 8). National landings (Fig. 9A) increased to a peak of 138483 in 2006, before falling. This trend coincides with that seen for small pelagic species catches (Fig. 9B). The proportion of these species in landings (80\%) clearly influences overall catch. Demersal species (Fig. 9C), molluscs (Fig. 9F) and (to varying degrees) large pelagics (Fig. 9D) contributed to the rise in overall landings during the early years. However, the continuing rise in demersals did not counterbalance the declining trend for total catch during the last few years. Crustaceans (Fig. 9E) fell by around 1000 tonnes until 2007, before catch began to rise again. Among the trophic indicators, after rising slightly from 1999 to 2004 , the P/D index fell significantly, reaching its lowest value of around 5 at the end of the series (Fig. 10A). The MTI fell from 3.25 to 3.22 between 1999 and 2003 (Fig. 10B) and then rose, reaching 0.07TL in 2010. The ${ }^{3.25}$ MTI fell by around 0.1TL between 1999 and 2007 (Fig. 10C). Following this, it entered a rising trend because of a significant demersal species catch in the later years. The FiB values were positive during the whole period studied, except in the last year, when a value of -0.16 was recorded (Fig. 10D). In fact, following a period of increase with a peak of 0.13 in 2006, the FiB fell, reaching a low of -0.16 in the last year of the series. The trends for landings and the FiB index coincide. The rise in the FiB is accompanied by the rise in overall catch and vice versa.

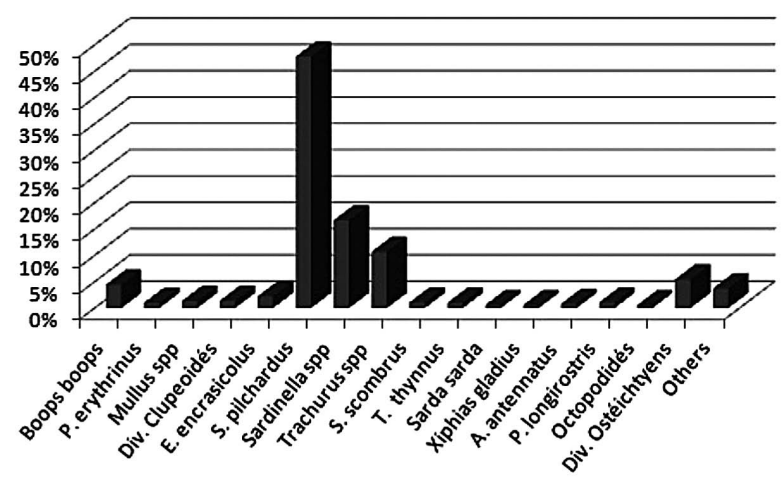

Fig. 8. - Species composition of landings at national level. 
A

Total landings (Algeria)

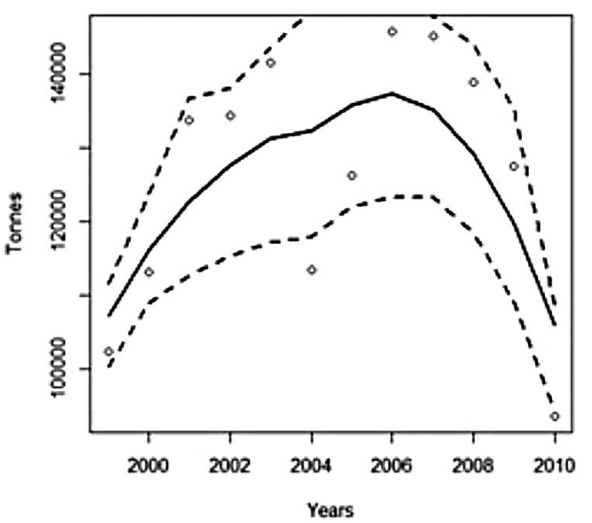

c

Demersal nsh (Algeria)

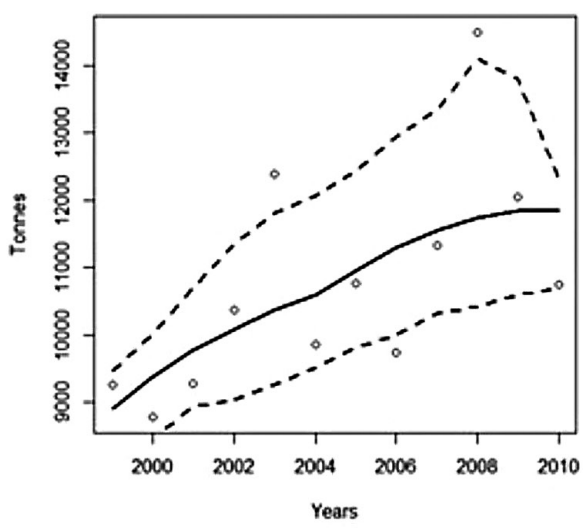

E Crustaceans (Algeria)



B

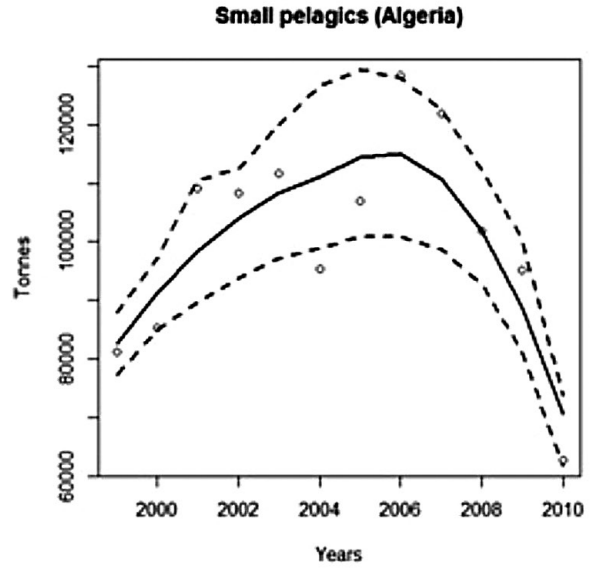

D
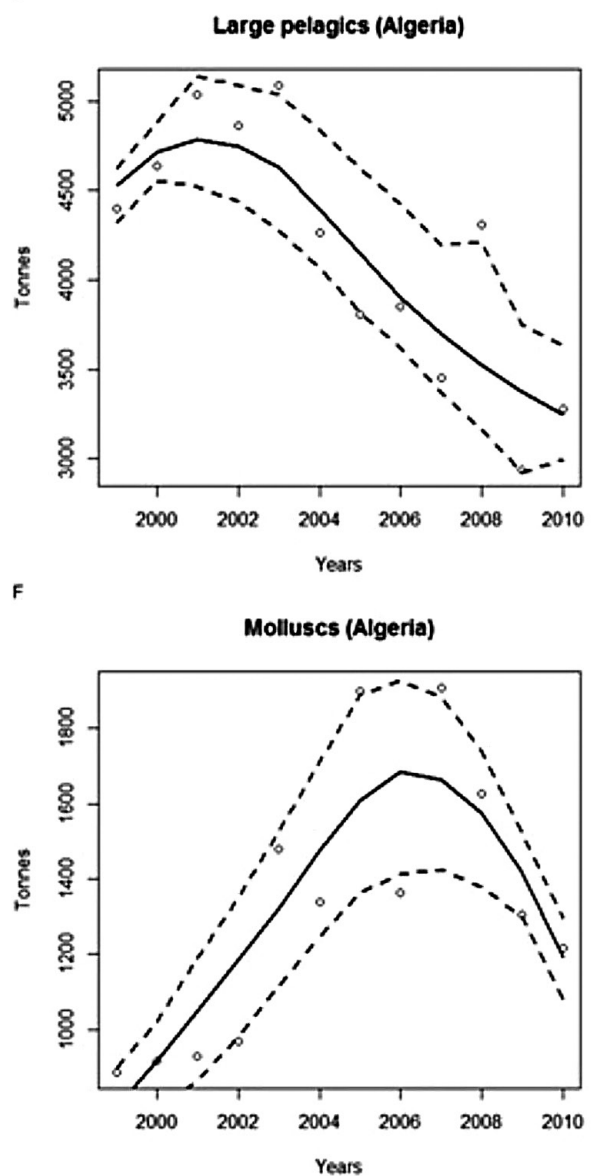

Fig. 9. - Overall landings and landings by species group of Algerian marine fisheries from 1999 to 2010 : total landings (A), small pelagics (B), demersal fish (C), large pelagics (D), crustaceans (E) and molluscs (F).

\section{DISCUSSION}

\section{On the Bou-Ismail Bay}

The Bou-Ismail Bay Fishery, like most Mediterranean fisheries, is characterized by the dominance of small pelagic species. This is reflected in the high values recorded for the P/D index. The average for the ratio in this bay, a value of 9.9, is far higher than those calculated for other Mediterranean regions (Pennino and Bellido 2012, De Leiva Moreno et al. 2000). This could be because of the different spatial-temporal scale and the species taken into consideration when calculating the ratio. It seems useful to carry out micro-level studies for this type of indicator, because of the existence of specific characteristics for each fishery and the related ecosystems, which can be hidden on a larger scale. The P/D ratio is much more heavily influenced by landings of Clupeoid species, primarily sardines (Sardina pilchardus) and round sardinella (Sardinella aurita), which represent over $73 \%$ of overall catch. The P/D ratio is characterized by a very large initial 

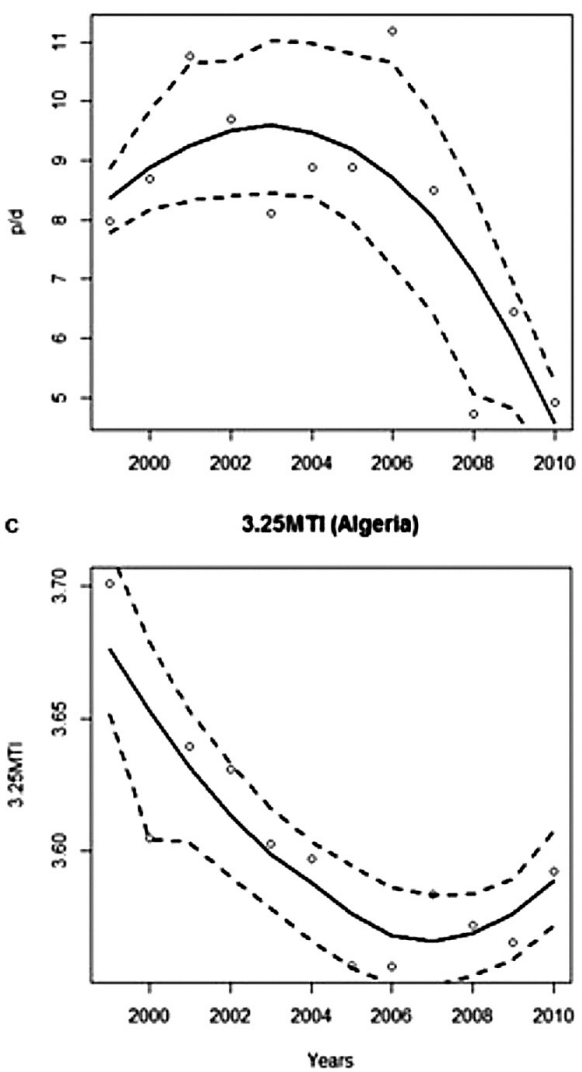

B
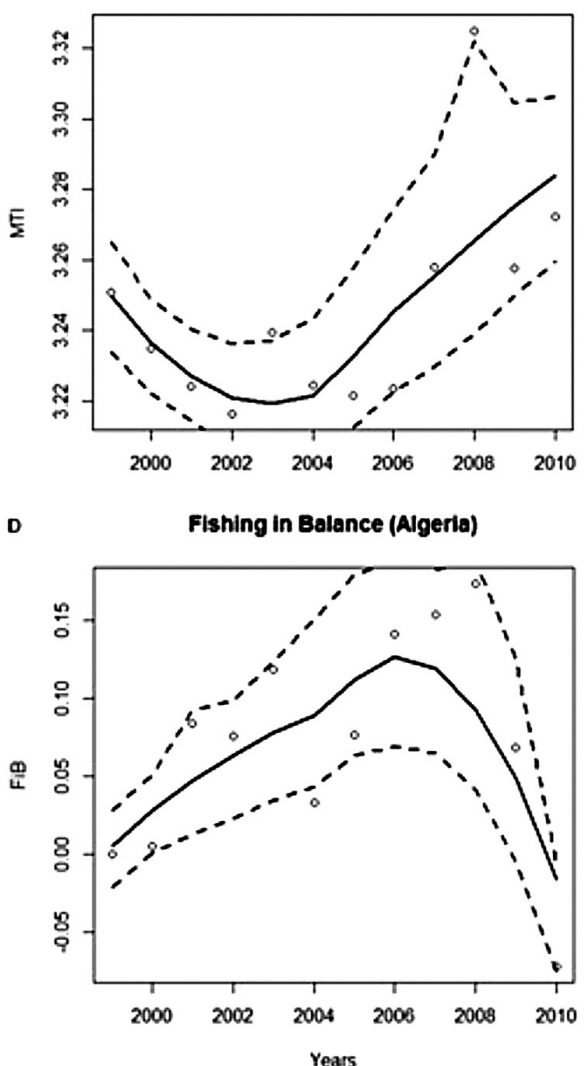

Fig. 10. - Trophic indicators for Algerian waters from 1999 to 2010.

decrease, then an increase over the very last years. The initial situation is due to the fall in small pelagic species and the increase in demersal fish within landings. The increasing scarcity of small pelagics, along with an increased fishing effort, suggests that these species are overexploited. In fact, despite rising primary production and nutrient input, which are favourable to these planktivorous species (Caddy 1993), their catch has fallen significantly, particularly in the case of sardine (Sardina pilchardus), whereas catches of the other small pelagic species (round sardinella, or Sardinella aurita) have increased in the latter years.

However, the increase in demersal fish catch is probably due to the increased fishing effort. In fact, over the last decade, several incentives funded by state subsidies have been introduced as part of the national development plan for fishing activities and aquaculture, and other programs have allowed for the growth and modernization of the fishing fleet. This increased fishing pressure is probably the reason behind the increased catches of these species, particularly pagellus (Pagellus spp.) and red mullet (Mullus spp.), in the first few years. However, the last four years of the series saw a fall in demersal fish catch, probably because of overexploitation (given the increased fishing effort) and/or eutrophication. In fact, the latter phenomenon, reflected in the increased primary production indicators (Chl- $a$ and SST), preceded and probably caused the fall in demersal fish catch.

Eutrophication causes hypoxia situations, which have a negative effect on benthic species (Caddy 1993).
Moreover, fairly high pollution levels have been observed in this zone (Houma 2009, PNUE 2005). These can also cause hypoxia. The start of a rise in the P/D ratio can indicate FDMW. This situation, as already observed in the Mediterranean (Pennino and Bellido 2012), indicates that the fishery increasingly targets small pelagic fish from the bottom levels of the trophic chain, such as round sardinella, for which catch was high during the latter years.

The ability to identify patterns consistent with FDMW has been discussed in considerable detail in the literature, along with the different conditions and data issues that could lead to similar patterns being identified that do not result from FDMW but from a range of fishery exploitations patterns throughout the food web (Essington et al. 2006, Litzow and Urban 2009, Branch et al. 2010, Sethi et al. 2010). Each of these fishery exploitations patterns should be contrasted to offer alternative explanations to FDMW.

The lowest MTI values were recorded between 1999 and 2003, and correspond to high catches of Clupeidae of low TLs (an estimated 3.1 for sardines, and 3.13 for round sardinella). The high catches of these two species, accounting for over $72 \%$ of total landings, are the reason for the lowest recorded MTI figures. However, the increase in the MTI coincides with the lowest landings of sardines (Sardina pilchardus). The increased catches of the main demersal fish species from relatively high TLs during the first years, and their decreases during the last years, did not counterbalance the MTI trend. The predominance of small pelagics can 
mask a possible effect of fishing on the trophic chain at medium and high TLs. Consequently, this indicator is unreliable for use in semi-enclosed seas, because of coastal phenomena such as eutrophication, which affects the abundance of small pelagic species and consequently impacts on their presence in landings. This can be confused with the effects of fishing (Caddy et al. 1998).

It therefore appears difficult to interpret the evolution of this index in a fishery greatly composed of small pelagics that are very vulnerable to environmental conditions. Consequently, the ${ }^{3.25}$ MTI (Pauly and Watson 2004) is an alternative to the MTI that reduces the influence of environmental conditions in the analysis of the effects of fishing on the trophic chain. The falling ${ }^{3.25} \mathrm{MTI}$, which indicates a decrease in the average TL of catch, suggests that the fishery is progressively targeting species from lower down in the trophic chain, probably because fish from upper TLs have been overexploited. The fall in the average TL of fish caught, combined with declining catches, where the fishing zone or gear usage has not changed, may indicate a collapse of the food chain (Pauly et al. 2001). The decrease, estimated at around 0.07 TLs for the 14 years studied, is close to that estimated by Pauly et al. (1998) at global level: around 0.1 per decade. However, it is far higher than those found in the Mediterranean by Pinnegar et al. (2003) ( 0.07/36 years), which include aquaculture. However, these authors use the MTI indicator and study larger temporal series and scales. The FiB decreased throughout the whole period studied. This decrease was accompanied by an increase in the fishing effort, decreasing catch, and a fall in average TL $\left({ }^{3.25} \mathrm{MTI}\right)$. This indicates a serious problem: it suggests overexploitation on the scale of the ecosystem (Chassot 2005) and the exhaustion of inshore stocks (Bathal 2005), given the coastal nature of this fishery. The decrease in the FiB can be seen as the result of a modification in the trophic structure of the ecosystem, and of an alteration of its operation (Cury et al. 2005b, Pauly and Watson 2005). This is confirmed by the trend in the average TL of catches, which decreased by $\sim 0.07$ TL over the 14 years studied.

This trend towards a fall in the average TL of catch has not been accompanied by a rise in catch. Such a result would have justified a deliberate choice to displace efforts towards the bottom of the food chain: towards the more productive lower components of the trophic network. However, this did not happen. In fact, the FiB decreased during the period studied (Freire and Pauly 2010). Moreover, discards are not taken into account in the catch data, which may partly explain this trend in the FiB (Pauly and Watson 2005). This analysis of the FiB suggests that fishing in the Bou-Ismail Bay removes so much biomass from the ecosystem that its functioning is affected (Pauly and Watson 2005).

It is worth noting that despite recent criticisms of the FiB index as an indicator for proving that ecosystems are being degraded by fishing (Hornborg et al. 2013), we understand that it may still be a suitable indicator for showing the changes occurring in the ecosystem, but only if used complementarily with other indices.

\section{On the Algerian waters and comparisons with the Bou-Ismail Bay}

The comparison between the Bou-Ismail Bay and the national level is essential since certain phenomena appearing on a small scale can be hidden on a large scale (Bhathal 2005). The average annual landings of the Bou-Ismail bay are estimated at $6889 \mathrm{t} / \mathrm{y}$. They represent nearly $5 \%$ of the national landings estimated at $126300 \mathrm{t} / \mathrm{y}$, considering the same period between 1999 and 2010. However, the specific structure resembles and both them are characterized by the dominance of small pelagic species, mainly in the order of importance, sardine (Sardina pilchardus), sardinella (Sardinella aurita) and horse mackerel (Trachurus spp.).

The fall in the P/D ratio is caused by the decline in small pelagic catch despite the increased nominal fishing effort (with a near $70 \%$ rise in the number of sardine boats and seiners from 1999 to 2009 (http://www. mpeche.gov.dz) as a result of the sector development policy from 1999 onwards. This situation indicates the overexploitation on the Algerian coasts of small pelagic species, particularly sardines, for which catches are constantly falling (as in the Bou-Ismail Bay). The increased demersal fish catch at national level is due to the near $70 \%$ increase in the number of trawlers from 1999 to 2009, and an increase of around 100\% in the number of small traders (http://www.mpeche. gov.dz). However, this increase can mask a situation of overexploitation for these species in the coastal zone, and maybe in some particular local sites hypoxia, as indicated for the Bou-Ismail Bay. In fact, new and more powerful trawlers, equipped with full modern navigational equipment, have been acquired with state subsidies with the aim of encouraging fishing in the high seas. The average TL of catch, including species from $\mathrm{TL}<3.25$ (MTI), is highly influenced by landings of small pelagic species, as is the case in the BouIsmail Bay. It increases when catches of small pelagic species increase, and vice versa. As a result, a probable FDMW situation can be masked by these low-TL species, which are highly affected by environmental conditions. Consequently, we will use the ${ }^{3.25} \mathrm{MTI}$ as the basis for our evaluation of the influence of fishing on the food chain in the ecosystem of the Algerian waters.

After eliminating from the calculation all species with a TL $<3.25\left({ }^{3.25} \mathrm{MTI}\right)$, including small pelagics, detritivores and certain invertebrates, the average TL of catch decreases from 3.67 to 3.59 ( 0.08TL/12 years). This decrease is very close to that of the Bou-Ismail Bay ( 0.07/14 years), suggesting a situation of FDMW in the upper and middle TLs on the scale of the ecosystems exploited by fishing in the Algerian Mediterranean. An increase during the final period of the time series is seemingly due to the rise in catches of certain demersal species from high TLs, as a probable result of the exploitation of new zones by the new trawlers.

The FiB at national level exhibited positive values almost throughout the period studied, with an initial period of increase, followed by a decrease in the later years. The initial rise in the FiB indicates either an expansion of fishing or a "bottom-up" effect, via the 
Table 3. - "Trade-off" table summarizing the trophic indicators studied, with landings, fleet information, and data on environmental variables for the Bou-Ismail Bay. $\downarrow$, falling trend; $\uparrow$, rising trend; $\uparrow \downarrow$, increase followed by decrease; $\downarrow \uparrow$, decrease followed by increase; $\leftrightarrow$, Stable trend; + , parameter directly influencing the trend of the indicator.

\begin{tabular}{|c|c|c|c|c|c|c|c|c|c|c|c|c|c|c|c|c|c|}
\hline $\begin{array}{l}\text { Environmental } \\
\text { variables }\end{array}$ & Landings & Fleet & & & & & & & & & & & & & & & \\
\hline & & & 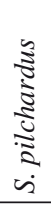 &  & 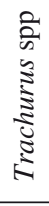 & $\begin{array}{c}\tilde{2} \\
\vdots \\
\vdots \\
\infty\end{array}$ & 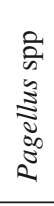 &  & $\begin{array}{l}2 \\
\vdots \\
0 \\
0 \\
0 \\
0 \\
0 \\
0 \\
0\end{array}$ &  & 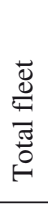 & 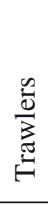 &  & 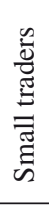 & & & \\
\hline$\uparrow$ & $\uparrow$ & $\downarrow$ & $\downarrow$ & $\downarrow \uparrow$ & $\downarrow$ & $\leftrightarrow$ & $\uparrow \downarrow$ & $\uparrow \downarrow$ & $\downarrow$ & $\downarrow$ & $\uparrow$ & $\uparrow$ & $\uparrow$ & $\uparrow$ & & & Conclusions \\
\hline $\mathrm{P} / \mathrm{D}$ & $\downarrow$ & + & + & & + & + & & + & + & + & & & + & + & + & + & $\begin{array}{l}\text { - Overexploitation of } \\
\text { S. pilchardus, } \\
\text { - Overexploitation } \\
\text { exacerbated by the hy- } \\
\text { poxia of demersal fish } \\
\text { except Boops boops. }\end{array}$ \\
\hline MTI & $\uparrow \downarrow$ & & & + & + & + & & & & & & & & & & & $\begin{array}{l}\text { Fishing down marine } \\
\text { webs (FDMW) masked } \\
\text { by small pelagic spe- } \\
\text { cies landings }\end{array}$ \\
\hline$\left.{ }^{3.25} \mathrm{MTI}\right)$ & $\downarrow$ & & & & & & + & + & + & + & + & + & & & & & FDMW \\
\hline $\mathrm{FiB}$ & $\downarrow$ & & & + & + & + & + & + & + & + & + & + & + & + & + & + & $\begin{array}{l}\text { Ecologically unsus- } \\
\text { tainable fishery }\end{array}$ \\
\hline $\begin{array}{c}\text { STATE OF THE } \\
\text { ECOSYSTEM }\end{array}$ & & $\Delta \mathrm{I}$ & & & & & & & & & & & & & & & \\
\hline
\end{tabular}

increase of primary productivity (Pauly and Watson 2005). Both scenarios should be envisaged, though the "bottom-up" effect is more likely, since the average TL of catch is falling.

In fact, the expansion of fishing is perhaps caused by the exploitation of new zones by the new, powerful and well-equipped offshore trawlers. These were acquired as part of the plan to incentivize the fishing sector, the first being in 2003. This is reflected particularly by the increase in demersal fish landings. On the other hand, the Mediterranean Sea is a semi-enclosed sea, highly affected by nutrient inputs (Caddy and Garibaldi 2000). In fact this is the case of Algerian coasts, which are enriched not only by soil runoff, but also by nutrients from waters of Atlantic origin. It is likely that this source of nutrients may have favoured the increase in the biomass of small pelagic species decrease in the TL of catches.

Hence, we conclude that the results from Algerian waters are rather similar to those obtained at the level of the Bou-Ismail bay, particularly for the last years, and both show similar trends, suggesting an alteration of the mechanics of the underlying ecosystem, probably caused by overfishing (Daskalov 2002).

\section{"Trade-off" table}

Catch-based ecosystem indicators do not necessarily give a reliable representation of the ecosystem (Branch et al. 2010). However, they are useful for providing information about the methods of exploitation which could undoubtedly arise from a change in abundance or from a fishing strategy, as a consequence of the management policy or economic dynamic (Gué- nette and Gascuel 2012). However, the indicators should be combined and analysed together, in order to obtain an overall picture of the ecosystem dynamic. For example, interpreting a single indicator such as MTI could give misleading results, as demonstrated in this study, where it increased rather than decreasing.

The results of the indicators studied for the Bou-Ismail Bay, combined with the environmental variables and the available data on fisheries (such as landings and fleet data) are summarized in a "trade-off" table (Table 3), to facilitate their interpretation and create a "toolbox" for implementing an EAFM. The decrease in the FiB, accompanied by a fall in the TL of catch ( $\left.{ }^{3.25} \mathrm{MTI}\right)$ and in the P/D, allows the Bou-Ismail Bay's ecosystem to be classified as an alert zone signifying unsustainable management of this zone. Consequently, this fishery requires immediate planning measures, such as a reduced fishing effort and stronger controls to avoid stock collapse.

This "trade-off" table remains purely indicative. It requires completion by other results concerning fisheries in other regions of the Algerian coast, in order to permit comparisons and probably define other zones that could serve as toolboxes for management needs. This could offer an alternative to the cumbersome model requiring large amounts of data on recruitment, size-weight relationships, and other unavailable and difficult-to-obtain biological data.

In conclusion, the use of trophic indicators in the evaluation of ecosystems subject to fishing offers an alternative to complex models requiring huge amounts of data which are not always available. This is particularly the case is studies of Algerian fisheries (for which data are often scarce). Consequently, we wish 
to encourage other studies of this kind, evaluating all fisheries at national level using longer historical series and locally-established TLs distributed according to size, in order to obtain the best possible results.

\section{REFERENCES}

Aminot A., Chausse-Pied M. 1983. Manuel des analyses chimiques en milieu marin. Edition: CNEXO, Brest, France, 395 pp.

Bhathal B. 2005. Historical reconstruction of Indian marine fisheries catches, 1950-2000, as a basis for testing the "Marine Trophic Index". Fisheries Centre Research Reports 13(4). Fisheries Centre, University of British Columbia, Vancouver, Canada.

Branch T. A., Watson R., Fulton E. A., Jennings S., Carey R., McGilliard C. R., Grace T., Pablico G. T., Ricard D., Tracey S. R. 2010. The trophic fingerprint of marine fisheries. Nature 468: 431-435. http://dx.doi.org/10.1038/nature09528

Caddy J. F. 1993. Toward a comparative evaluation of human impacts on fisheries ecosystems of enclosed and semi enclosed seas. Rev. Fish. Sci. 1: 57-95. http://dx.doi.org/10.1080/10641269309388535

Caddy J. F. 2000. Marine Catchment Basin effects versus impacts of fisheries on semi-enclosed seas. ICES J. Mar. Sci. 57: 628-640. http://dx.doi.org/10.1006/jmsc.2000.0739

Caddy J. F., Csirke J., Garcia S. M., Grainger R. J. R. 1998. How pervasive is 'Fishing down marine food webs?' Science 282(5393): 1383-1383. http://dx.doi.org/10.1126/science.282.5393.1383a

Caddy J. F., Garibaldi L. 2000. Apparent changes in the trophic composition of world marine haversts: the perspective from FAO capture database. Ocean Coastal Management. Fish Res. 72: 241-252.

CBD 2004. Annex I, decision VII/30. The 2020 biodiversity target: a framework for implementation. Decisions from the Seventh Meeting of the Conference of the Parties of the Convention on Biological Diversity, Kuala Lumpur, 9-10 and 27 February 2004. Secretariat of the CBD, Montreal.

Chassot E. 2005. Approche Ecosystémique des Pêches: De l'utilisation d'indicateurs à la simulation théorique; vers un modèle couplé écologie/économie appliqué au Finistère. Thèse Doctorat, Ecole Nationale Superieure Agronomique de Rennes. $310 \mathrm{pp}$.

Christensen V. 1998. Fishery-induced changes in a marine ecosystem: insights from the models of the Gulf of Thailand. J. Fish Biol. 53: 128-142. http://dx.doi.org/10.1111/j.1095-8649.1998.tb01023.x

Christensen V. 2000. Indicators for marine ecosystems affected by fisheries. Mar. Freshwater Res. 51: 447-450. http://dx.doi.org/10.1071/MF99085

Cleveland R. B. 1979. Robust locally-weighted regression and smoothing scatterplots. J. Amer. Statist. Assoc. 74: 829-836. http://dx.doi.org/10.1080/01621459.1979.10481038

Cury P.M., Mullon C., Garcia S.M., Shannon L.J. 2005a. Viability theory for an ecosystem approach to fisheries. ICES J. Mar. Sci. 62: 577-584. http://dx.doi.org/10.1016/j.icesjms.2004.10.007

Cury P. M., Shannon L. J., Roux J-P., Daskalov G. M., Jarre A., Moloney C. L., Pauly D. 2005b. Trophodynamic indicators for an ecosystem approach to fisheries. ICES J. Mar. Sci. 62: 430-442. http://dx.doi.org/10.1016/j.icesjms.2004.12.006 Daskalov G.M. 2002. Overfishing drives a trophic cascade in the Black Sea. Mar. Ecol. Prog. Ser., 225: 53-63. http://dx.doi.org/10.3354/meps225053

De Leiva Moreno J. I., Agostini V. N., Caddy J. F., Carocci F. 2000. Is the pelagic-demersal ratio from fishery landings a useful proxy for nutrient availability? A preliminary data exploration for the semi-closed seas around Europe. ICES J. Mar. Sci. 57: 1091-1102. http://dx.doi.org/10.1006/jmsc.2000.0705

Efron B. 1979. Bootstrap methods: Another look at the Jackknife. Ann. Stat. 7: 1-26. http://dx.doi.org/10.1214/aos/1176344552

Essington T.E., Beaudreau A. H., Wiedenmann, J. 2006. Fishing through marine food webs. Proc. Natl. Acad. Sci. USA 103(9): 3171-3175.

http://dx.doi.org/10.1073/pnas.0510964103

FAO 1995. Code de conduite pour une pêche responsable. FAO,
Rome, Italy.

FAO 2001. Indicateurs pour le développement durable des pêcheries marines. Directives techniques pour une pêche responsable No 8. FAO, Rome, Italie.

FAO 2003. L'approche écosystémique des pêches. Directives techniques pour une pêche responsable. No. 4, Suppl. 2. Rome, Italy. 120 pp.

FAO 2010. La situation mondiale des pêches et de l'aquaculture. FAO, Rome, Italy.

Freire K., Pauly D. 2010. Fishing down Brazilian marine food webs, with emphasis on the east Brazil large marine ecosystem. Fish. Res. 105(1): 57-62 http://dx.doi.org/10.1016/j.fishres.2010.02.008

Froese R., Pauly D. 2013. FishBase. Accessed Feb. 2013. www. fishbase.org.

Garcia S. M., Cochrane K. L. 2005. Ecosystem approach to fisheries: a review of implementation guidelines. ICES J. Mar. Sci. 62: 311-318. http://dx.doi.org/10.1016/j.icesjms.2004.12.003

Garcia S. M., Zerbi A., Aliaume C., Do Chi T., Lassarre G. 2003. The ecosystem approach to fisheries. FAO Rep 443, Rome.

Gislason H., Sinclair M., Sainsbury K., O’Boyle R. 2000. Symposium overview: incorporating ecosystem objectives within fisheries management. ICES J. Mar. Sci. 57: 468-475. http://dx.doi.org/10.1006/jmsc.2000.0741

Guénette S., Gascuel D. 2012. Shifting baselines in European fisheries: The case of the Celtic Sea and Bay of Biscay. Ocean Coast. Manage. 70: 10-21 http://dx.doi.org/10.1016/j.ocecoaman.2012.06.010

Hemida F. 2005. Les sélaciens de la cote algérienne: Biosystématique des Requins et des Raies. Ecologie, Reproduction et Exploitation de quelques populations capturées. $\mathrm{PhD}$ thesis, USTHB (Alger), $231 \mathrm{pp}$.

Houma B. F. 2009. Modélisation et cartographie de la pollution marine et de la bathymétrie à partir de l'imagerie satellitaire. $\mathrm{PhD}$ thesis, Univ. du Val de Marne Paris XII (France), $274 \mathrm{pp}$.

Hornborg S., Svensson M., Nilsson P., Ziegler F. 2013. By-Catch Impacts in Fisheries: Utilizing the IUCN Red List Categories for Enhanced Product Level Assessment in Seafood LCAs. Environ. Manage. 52(5):1239-1248. http://dx.doi.org/10.1007/s00267-013-0096-7

Jaureguizar A. J., Milessi A. C. 2008. Changes in species composition and trophic level of landing in the Argentine-Uruguayan Common Fishing Zone (1989-2003). Sci. Mar. 71: 25-36.

Libralato S., Pranovi F., Raicevich S., Da Ponte F., Giovanardi O., Pastres R., Torricelli P., Mainardi D. 2004. Ecological stages of the Venice Lagoon analyzed using landing time series data. J. Mar. Syst. 51: 331-334 http://dx.doi.org/10.1016/j.jmarsys.2004.05.020

Link J.S. 2002. What does ecosystem-based fisheries management mean? Fisheries 27: 18-21.

Litzow M. A., Urban D. 2009. Fishing through (and up) Alaskan food webs. Can. J. Fish. Aquat. Sci. 66(2): 201-211. http://dx.doi.org/10.1139/F08-207

Massuti E., Ordinas F., Guijarro B., Pomar B., Fliti K., Refes W., Zaghdoudi S., Bouaicha M., Reghis M., Miraoui M, Naili R., Ait Ferroukh B. 2004. Informe de la campa-a Argelia 0204 para la evaluación de recursos démersales en las costas de Argelia (Mediterráneo Sud Occidental). IEO, MPRH, SGPM, 123 pp.

Morishita J. 2008. What is the ecosystem approach for fisheries management? Mar. Policy 32: 19-26. http://dx.doi.org/10.1016/j.marpol.2007.04.004

Pauly D., Christensen V. 1995. Primary production required to sustain global fisheries. Nature 374: 255-257. http://dx.doi.org/10.1038/374255a0

Pauly D., Watson R. 2004. Fisheries impact on global marine diversity and ecosystems: inferences from large heterogeneous data sets. Ocean Biodiversity Informatics. 29 Nov-1 Dec.

Pauly D., Watson R. 2005. Background and interpretation of the 'Marine Trophic Index' as a measure of biodiversity. Philos. T. Roy. Soc. B 360: 415-423. http://dx.doi.org/10.1098/rstb.2004.1597

Pauly D., Christensen V., Dalsgaard J. P. T., Froese R., Torres F. 1998. Fishing down marine food webs. Science 279: 860-863. http://dx.doi.org/10.1126/science.279.5352.860

Pauly D., Christensen V., Walters C. 2000. Ecopath, Ecosim, and Ecospace as tools for evaluating ecosystem impact of fisheries. ICES J. Mar. Sci. 57: 697-706. http://dx.doi.org/10.1006/jmsc.2000.0726

Pauly D., Palomares M.L., Froese R., Sa-a P., Vakily M., Preik- 
shot D., Wallace S. 2001. Fishing down Canadian aquatic food webs. Can. J. Fish Aquat. Sci. 58: 51-62.

http://dx.doi.org/10.1139/f00-193

Pennino M. G., Bellido J. M., 2012. Can a simple Pelagic-Demersal ratio explain ecosystem functioning? Biodiversity J. 3(1): 69-78.

Pennino M.G., Bellido J.M., Conesa D., López-Quílez, A. 2011. Trophic indicators to measure the impact of fishing on an exploited ecosystem. Anim. Biodivers. Conserv. 34.1: 123-131.

Pinnegar J.K., Polunin N.V.C., Badalamenti F. 2003. Long-term changes in the trophic level of western Mediterranean fishery and aquaculture landings. Can. J. Fish. Aquat. Sci. 60: 222-235. http://dx.doi.org/10.1139/f03-016

PNUE-PAM, CAR/ASP 2005. Programme d'Aménagement Côtier (PAC) "Zone côtière algéroise". Activité: Protection des sites sensibles naturels marins du secteur Cap Djinet au Mont Chenoua: Impacts des activités anthropiques. $88 \mathrm{pp}$.

R Development Core Team 2013. R: a language and environment for statistical computing. R Foundation for Statistical Computing, Vienna, Austria. ISBN 3-900051-07-0. URL http:// www.R-project.org.
Refés W., Semahi N., Boulahdid M. 2010. Diversité et biogéographie de l'ichtyofaune orientale de la côte algérienne. J. Sci. Hal. Aquat. 3: 54-66.

Sethi S.A., Trevor A.B., Reg W. 2010. Global fishery development patterns are driven by profit but not trophic level. Proc. Natl. Acad. Sci. USA. 107(27): 12163-12167. http://dx.doi.org/10.1073/pnas.1003236107

Stergiou K.I., Koulouris M. 2000. Fishing down the food webs in the Hellenic Seas. CIESM Workshop Series 12: 73-78.

Stergiou K.I., Karpouzi V.S. 2002. Feeding habits and trophic levels of Mediterranean fish. Rev. Fish Biol. Fish. 11: 217-254. http://dx.doi.org/10.1023/A:1020556722822

Worm B., Hilborn R., Baum J.K., Branch T.A., Collie J.S., Costello C., Fogarty M., J., Fulton E.A., Hutchings J.A., Jennings S., Jensen O.P., Lotze H.K., Mace P.M., McClanahan T.R., Minto C., Palumbi S.R., Parma A.M., Ricard D., Rosenberg A.A., Watson R., Zeller D. 2009. Rebuilding Global Fisheries. Science 325: 578-585.

http://dx.doi.org/10.1126/science.1173146 